\title{
The 'new' League success in the red belt and its post-fascist inheritance: evidence from 2018 National Elections
}

\author{
Moreno Mancosu ${ }^{1}$ (Collegio Carlo Alberto) \\ Riccardo Ladini² (University of Milan)
}

\begin{abstract}
In 2018 national elections, the Lega, an Italian xenophobic right-wing party, has dramatically increased its consensus in the 'red belt', the central part of the country traditionally ruled by center-left parties. Pundits have argued that this performance can be attributed to the effect of the new leadership of Matteo Salvini, who shifted the ideological location of the party (that now aims at being a national right-wing party), combined with the drop in preferences of Forza Italia, the ally/competitor in the right-wing ideological spectrum. This paper aims at providing new insights in the explanation of these electoral outcomes, by hypothesizing that geographical trajectories of diffusion of the party are correlated with the presence of geographically clustered post-fascist minorities present in the region since the First Republic age. By employing official figures at the municipality level, the paper analyses the relationship between the percentages of votes for the MSI (the most relevant post-fascist force during the First Republic) in 1976 and the Lega Nord in the 2006-2018 period. Consistent with our hypothesis, the post-fascist inheritance is significantly correlated with the local prevalence for the Lega Nord in 2018, after the change in the political discourse and leadership of the party. Empirical analyses provide evidence of our expectations, even when controlling for unemployment rate and percentage of immigrants.
\end{abstract}

Keywords: electoral geography, Italian politics, Lega Nord, right-wing parties

This is a preliminary draft. Please do not cite or distribute without permission of the authors.

\footnotetext{
1 moreno.mancosu@carloalberto.org

2 riccardo.ladini@unimi.it
} 


\section{Introduction}

In Italian political science literature, the role of the so-called 'leaguism' (Tarchi, 1998) has been deeply analyzed since the early 1990s, when the appearance of the Lega Nord in the political spectrum contributed crucially to the end of the First Republic.

Since its birth, the party manifesto had been based on typical ethno-regionalist goals, such as the promotion of knowledge of local history and culture, and demands for the transfer of powers to local administrations (Agnew, 1995; Tarchi, 1998). During more than 25 years of presence in the Italian political landscape, the Lega has passed through several vicissitudes, by both gaining relevant shares of votes (for instance, in 1992 and 1996) and reaching very low levels of support (for instance, 2013 national elections). One of the steady characteristics of the trend of expansion and contraction of the movement, however, consisted of the boundaries inside which the voting pattern took place (Segatti and Vezzoni, 2011). As pointed out by Passarelli and Tuorto (2014, 420), 'the Lega not only symbolically evoked the role of territory in its political mission but also had a geographically well-defined electoral background since its establishment': even if we consider the party's strongest performances, relevant results were always confined in northern Italian regions, roughly until Emilia-Romagna (see Passarelli and Tuorto, 2014). The Lega, indeed, never succeeded in central regions, the so-called 'red belt', which had been dominated by center-left parties since the immediate post-war period (Galli, 1968; Sani, 1976; Diamanti, 2003; Anderlini, 2007).

This consolidated pattern started to change substantially with the results of 2015 regional elections. In that occasion, the Lega obtained significant percentages in central regions, such as Tuscany, Umbria, and Marche, traditionally hostile to the party (D'Alimonte, 2015). The Carroccio became, in those regions, the second party in the political spectrum, after the center-leftist Partito Democratico, acquiring more than 250,000 votes with respect to the 2014 European Elections. That figure was further reinforced in 2018 national elections, in which the consensus of the Lega showed an increase of about 600,000 votes compared to previous general elections (in 2013, the party obtained only 25,699 votes in Tuscany, Umbria, and Marche).

From the supply-side, we can at least find two explanations of this exploit: the first focuses on the change of leadership in the Lega (D’Alimonte, 2015; Albertazzi et al., 2018). After over 20 
years of the guidance of Umberto Bossi, in 2013 the leadership passed to Matteo Salvini, who progressively changed the discourse and the aims of the party (Albertazzi, 2016). Indeed, the new course of the Lega led by Salvini is no more solely oriented to northern Italian regions. Instead, Salvini's efforts are aimed at creating an extreme-right-wing national party, focused on anti-immigrant and anti-European claims, similarly to Marine Le Pen's Front National in France (Brunazzo and Gilbert, 2017). According to pundits and commentators, the nationalization process of the Lega led the party to become a much more viable political option for the center-right electorate (Diamanti, 2015). Combined with this interpretation, another political component of this success has been identified in the progressive loss of strength and appeal of the historical ally of the Lega, Forza Italia. The decrease of consensus of Berlusconi's party at the national level has left a free space in the right spectrum, leading to the positive result of the Carroccio.

Keeping in mind these supply-side explanations, our paper aims at investigating the role of the political traditions in the 2018 success of the 'new' Lega in the red belt. Our set of explanations will focus on the Lega as a party with a unique geographical history, in which the trajectories of its expansion are correlated with the traditional cleavages that have been present in the red belt since the first republic. Indeed, the red belt - far from being a monolithic region completely dominated by center-left parties - presents several places in which a small, but fierce, and geographically clustered post-fascist minority has been present since the First Republic. In this respect, our main hypothesis is that the strategy of the 'new' Lega, more related to extreme right-wing claims than regionalistic demands, might have led to a larger success in places where the post-fascist minority had been stronger during the First Republic (Agnew, 1992; Baccetti and Gabelli, 1998).

In order to control for alternative explanations to the expansion of the Lega in the center, we will take into account characteristics that the party shares with other extreme right-wing parties around Europe and the responses that voters tend to give to those parties. In this respect, the literature provides at least two main explanations of these parties' support on the territory: the 'modernization losers' and the 'racial threat' explanations (Betz, 1994; Beirich and Woods, 2000; Bowyer, 2008).

The aim of the article is not only confined in the analysis of a single case-study. While many studies in electoral geography have focused on the electoral inheritance of the major subcultures, 
less attention has been provided to the electoral continuity of what we will call 'minority political traditions'. Our work aims to shed light on this aspect which can give a crucial contribution in explaining the territorial variance of parties' performance.

Results confirm our hypotheses, by showing that the success of the Lega proves to be stronger in areas particularly favorable to the post-fascist minority during the First Republic. Moreover, it is argued that this phenomenon is somewhat new, since the correlation between the post-fascist minority's and the Lega's vote share is no longer consistent when we take into account the Lega's outcomes in the three previous national elections held before the ideological shift operated by Salvini $(2006,2008,2013)$.

\section{Background}

Among the several vicissitudes having affected the Lega Nord (for more information see Diamanti, 1993; Cartocci, 1994; Cento Bull and Gilbert, 2001; Passarelli and Tuorto, 2009; 2012), the last, and more important for our aims, concerns the turmoil that reset the leadership of the party in 2012. A fraud scandal hit directly the historical leader of the Lega, Umberto Bossi, who was forced to resign from his role of undisputed leader of the party (Albertazzi, 2016). After a brief interregnum managed by Roberto Maroni, in December 2013 the leadership of the Lega passed to a young leader of the party, Matteo Salvini.

Since the beginning of its office, Salvini characterized his political action further to the right wing with respect to Bossi's leadership. Several pundits have stressed that the actual aim of Salvini was to transform the old regionalist Lega into something new: a party radically rooted on the right-side of the political spectrum, that exploits with its rhetoric the anti-immigrant and anti-EU sentiments that are largely present in the Italian population (Albertazzi, 2016; Brunazzo and Gilbert, 2017). Furthermore, Salvini's political action has been devoted to turning the Lega into a fully national party (Albertazzi et al. 2018), that could count on votes of people far from the traditional geographical boundaries of the original Lega.

As pointed out by Albertazzi and colleagues (2018), the Lega claims indeed moved from a mainly regionalist focus on autonomy and federalism to a national focus on nativism and protectionism. In such respect, the Lega's main enemies shifted from the national level, namely Rome and the Southern Italians, to the supranational one, namely the EU, Brussels bureaucrats, 
and the immigrants (Albertazzi et al., 2018). As a result, it is relevant to remember the attempts of Salvini to organize electoral committees also in Southern Italy. Another indirect proof of this double shift (to the right of the political spectrum and the south of the country) can be found in the factual collaborations (and joint mobilization) of the Lega with other extreme right nationalist groups (Albertazzi, 2016)

According to Segatti and Vezzoni (2011), until the last electoral cycle, the electoral pattern of the Lega could be depicted as an expanding and contracting lung, confined to the northern regions of the country. In particular, they argued that when the political system proved to be more stable, the area of the consensus of the Lega became smaller, generally confined around its strongholds. In more turbulent political times, instead, the Lega came out from its traditional boundaries and spread its consensus in other areas, like the Western provinces of the Emilia-Romagna.

Nonetheless, a first territorial change of the Lega dates back to 2008 election, when it doubled its share of votes in Emilia-Romagna, (7.8\%, against the 3.9\% in 2006, see Passarelli and Tuorto, 2012)which represents one of the four regions of the red belt (Galli, 1968). Such support in that region was later confirmed both in 2009 European elections (11.1\%) and 2010 regional elections (13.7\%). In that period, scholars noticed a first sign of the nationalization of the Lega, which started to focus more on national than territorial issues (Diamanti, 2009). However, as Table 1 shows, the support of the Lega in the other regions of the red belt was still irrelevant. In 2006, 2008, and 2013 elections the percentage of votes for the Lega Nord in Tuscany, Umbria, and Marche oscillated between 0.7 and 2.2 per cent. In all the three elections, the performance of the Lega never exceeded the 10 per cent in any of the 618 municipalities. In those areas, the nationalization/radicalization of the Lega brought beneficial effects since the European Elections of 2014, when the Lega doubled its preferences at the country-level compared to 2013 National elections (6.2\% against 3.1\% in 2013). Later, the Lega succeeded beyond the wildest imagination of its supporters in 2015 regional elections, and furthermore in 2018 national elections, as reported in Table 1. Such electoral outcomes represent, thus, a unique circumstance in the history of the party. Although the Lega proved to be marginally stronger in Umbria (20.2\%), its performance has been outstanding even in Tuscany and Marche (more than 17\%). In Tuscany, the party obtained more than 10 per cent of the valid votes in every municipality, and in at least one 
municipality 1 out of 3 voters chose the Lega, as well as in Umbria ${ }^{3}$. This paper aims at explaining the pattern of this exploit by employing an electoral geopolitics approach (Galli, 1968)

Table 1: Descriptive statistics of Lega vote share by region (Tuscany, Marche, Umbria)

\begin{tabular}{llccccc}
\hline & & \multicolumn{5}{c}{ vote share (municipalities' distribution) } \\
& & $\%$ & Mean & Dev.std & Min & Max \\
\hline \multirow{2}{*}{ Tuscany } & LN-MpA 2006 & 1,1 & 1,2 & 0,7 & 0,0 & 5,3 \\
$(\mathrm{~N}=287)$ & LN 2008 & 2,0 & 2,2 & 1,1 & 0,3 & 6,7 \\
& LN 2013 & 0,7 & 0,8 & 0,4 & 0,0 & 2,5 \\
& Lega 2018 & 17,4 & 19,7 & 4,5 & 10,3 & 33,3 \\
& & & & & & \\
Marche & LN-MpA 2006 & 1,0 & 1,1 & 1,0 & 0,0 & 7,4 \\
$(\mathrm{~N}=239)$ & LN 2008 & 2,2 & 2,4 & 1,7 & 0,0 & 9,8 \\
& LN 2013 & 0,6 & 0,7 & 0,5 & 0,0 & 3,4 \\
& Lega 2018 & 17,3 & 19,5 & 4,8 & 8,4 & 49,3 \\
& & & & & & \\
Umbria & LN-MpA 2006 & 0,8 & 0,7 & 0,5 & 0,0 & 3,0 \\
$(\mathrm{~N}=92)$ & LN 2008 & 1,7 & 1,6 & 1,0 & 0,0 & 6,4 \\
& LN 2013 & 0,7 & 0,6 & 1,0 & 0,0 & 9,6 \\
& Lega 2018 & 20,2 & 21,6 & 4,3 & 7,2 & 33,9 \\
\hline
\end{tabular}

\subsection{The inheritance of political traditions}

Since seminal studies on electoral behavior in Italy (Galli, 1968; Sani, 1976), the territory has played a crucial role in the explanation of vote choice. The strong territorial organization of the

\footnotetext{
3. In addition to the shift of the political supply operated by the new leadership, several studies have argued that the success of the Lega is characterized by the correspondent defeat of Berlusconi's creature, Forza Italia, which obtained its historical minimum in those regions in 2015 regional elections (D'Alimonte, 2015, Corbetta et al., 2015). As other studies stressed, by means of the technique of ecological inference, in 2015 regional elections the Lega increases its support in the red belt with respect to the previous election (2014 European Election) mainly to the expenses of Forza Italia's voters and marginally of other center-right parties, such as the right-wing Fratelli d'Italia (Corbetta et al., 2015). Similar outcomes are detected when analyzing the electoral flows to the Lega Nord in 2018 national elections from votes in 2013 elections (Paparo and Cataldi, 2018). Overall, it emerges clearly how the party that is mainly affected by the Lega's rise is indeed Berlusconi's Forza Italia.
} 
two mass parties, which characterized the Italian First Republic (DC - Christian Democracy, and PCI - Italian Communist Party) were indeed reflected in their political subcultures. Depending on the party hegemony in a specific area and other socio-economic characteristics, Italy was subdivided into geopolitical areas (like the red belt here analyzed), which, even nowadays, are always taken into account when studying Italian voting behavior.

The disappearance of the two main political parties at the end of the First republic hugely increased the attention on the Italian context among electoral geography scholars, interested in analyzing the vote dynamics after the turmoil of the political system. Although in different ways, a territorial voting continuity between the First and Second republic parties emerged (Agnew, 1995, 1996; Shin and Agnew, 2002, 2007, 2008; Passarelli and Tuorto, 2012). Moreover, in addition to analyzing territorial voting dynamics in a relatively short time span, scholars also analyzed the persistence of political traditions in terms of voting patterns. By analyzing the relationship between the political tradition in the immediate post-war and the vote in 1972 at the municipality level, Sani (1976) argued that the DC had more consensus in places with a strong Catholic tradition, as well as the PCI in municipalities with a strong communist or socialist tradition. Even though the role of the political tradition has been progressively losing its prominence, Vezzoni (2008) showed continuity between the political traditions and vote in 2006 elections, especially in contexts where the DC or the PCI tradition was strong.

The study of the inheritance of the political traditions, however, has mainly focused on the major political subcultures. Nonetheless, even other political traditions were able to persist in contexts dominated by a major political subject (Galli et al., 1968), therefore, as Sani (1976) suggests, 'search for contextual forces shaping political attitudes should not be limited only to the identification of the major political tradition of the larger community' (p. 394). Also minor political traditions, indeed, could have had an enduring effect on voting behavior. It has been stressed above that the red belt has been dominated by center-left parties (the PCI during the First Republic and the PDS/PD in the Second). One might ask where does a right-wing section of electorate come from in such a left-wing region. Despite the striking and durable majority of left-wing ideology in the red belt, it is possible to notice sub-regional anomalies in which the support to the opposition parties has been always more pronounced. These clusters, already identified and investigated in previous studies (Agnew, 1992; Baccetti and Gabelli, 1998; Shin and Agnew, 2002) can be seen as something that we can call minority political traditions, 
enclaves in which the socio/political environment is different with respect to the vast majority of other parts of the territory. Some of these clusters have been investigated in depth: for instance, various studies explained the presence of small landownership and the Lucca's status as an independent republic as an explanation for the PCI's inability to be supported in those provinces, and the resulting strength of centrist and right-wing parties (Dogan, 1967; Agnew, 1992). As a result, even the red belt is not a politically homogeneous region.

When analyzing the electoral advancement of the Lega in Emilia-Romagna since 2008, Passarelli and Tuorto (2012) observed that the performance of the Lega was stronger in municipalities where the DC obtained more electoral consensus during the First Republic, similarly to the voting pattern of the Lega in other northern regions. Our work will thus provide evidence to test whether this relationship exists even in the other red belt regions. The term 'opposition party', in the red belt, might not only refer to the Christian Democrats (that is, the main traditional center-right party in the First Republic), but also to the more extremist Movimento Sociale Italiano - Destra Nazionale (Italian Social Movement - National Right, henceforth MSI). For decades, the MSI has been the fourth force in the Italian political spectrum, but it was kept outside governmental offices because of its post-fascist legacy (Ignazi, 1994; 2003; Tassani, 1990). We can thus say that the MSI represented, during the First Republic, the main political reference for the extreme right electorate (Ignazi, 1994). What this paper argues is that the process of extremization of the Lega, combined with the dismantlement of the regional rhetoric in favor of more nationalistic and extreme right-wing claims of Salvini's party, could have convinced this radical right-wing tradition (rooted in places where the MSI was stronger in the First Republic) to trust the new course of the nationalist Lega. Theoretically, we argue that the success of the Lega in the red belt can be successfully predicted by the distribution of extreme right-wing minority traditions that coexisted with the dominant left-wing majority since the First Republic. The minority post-fascist tradition is thus expected to be reflected in the voting pattern for the new Lega.

A first, intuitive clue of this idea can be seen in figures 1-3. The placement of the extreme right-wing minority tradition is in figure 1, where MSI strength during the First Republic (namely, the percentage over eligible voters of the MSI in the 1976 national elections) is mapped for the municipalities of Tuscany, Umbria, and Marche ${ }^{4}$.

\footnotetext{
4. To highlight and compare the areas where the Lega had on average a stronger (or weaker) performance, we used
} 
Figure 1. Spatial distribution of MSI in 1976 national elections

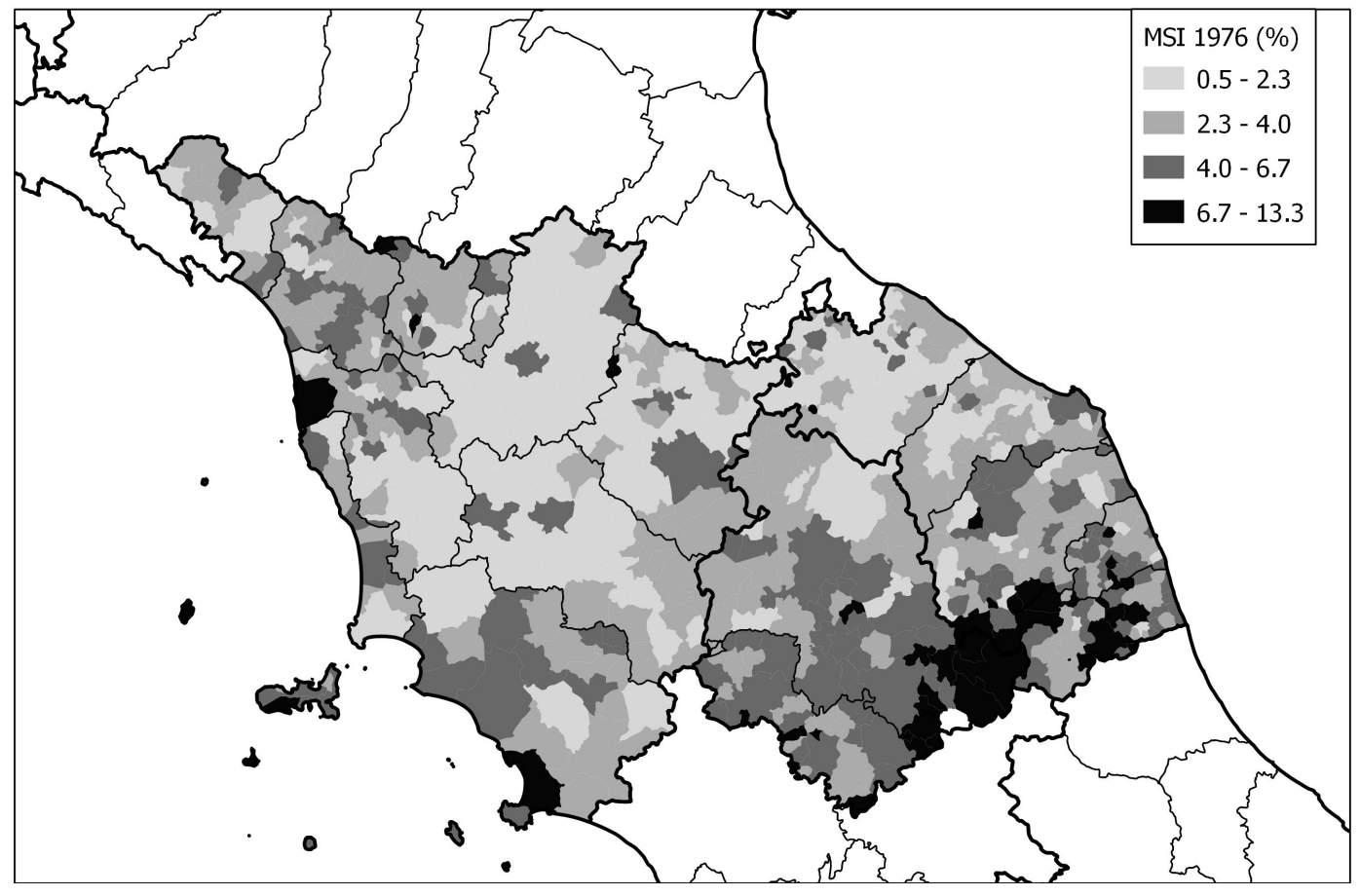

Figure 2. Spatial distribution of Lega Nord in 2008 national elections

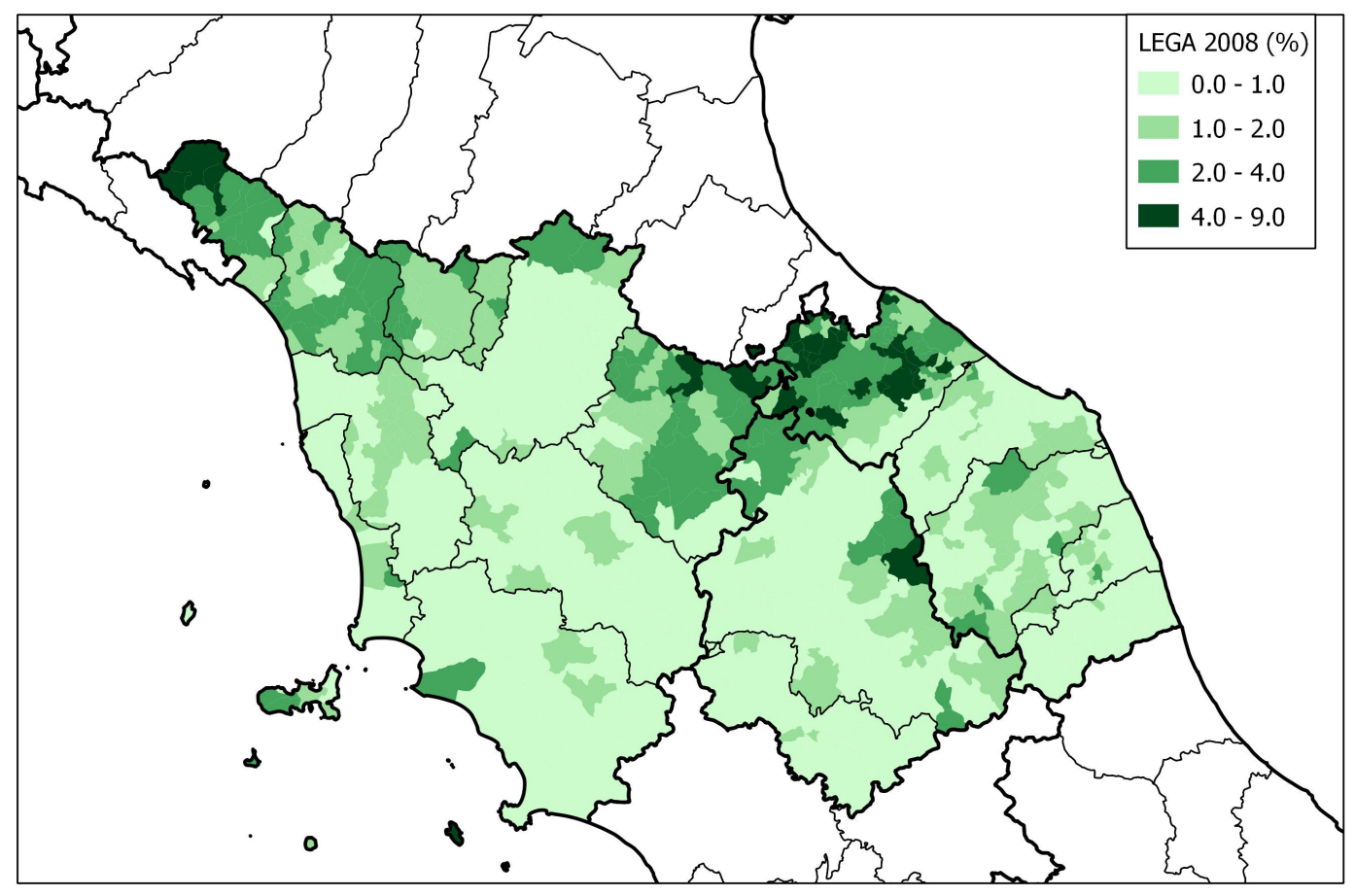

the same color graduation in the two maps of the Lega in 2008 and 2018 elections. Nonetheless, as the legends show, the classes of percentages of vote corresponding to the same color vary between the two maps. 
Figure 3. Spatial distribution of Lega in 2018 national elections

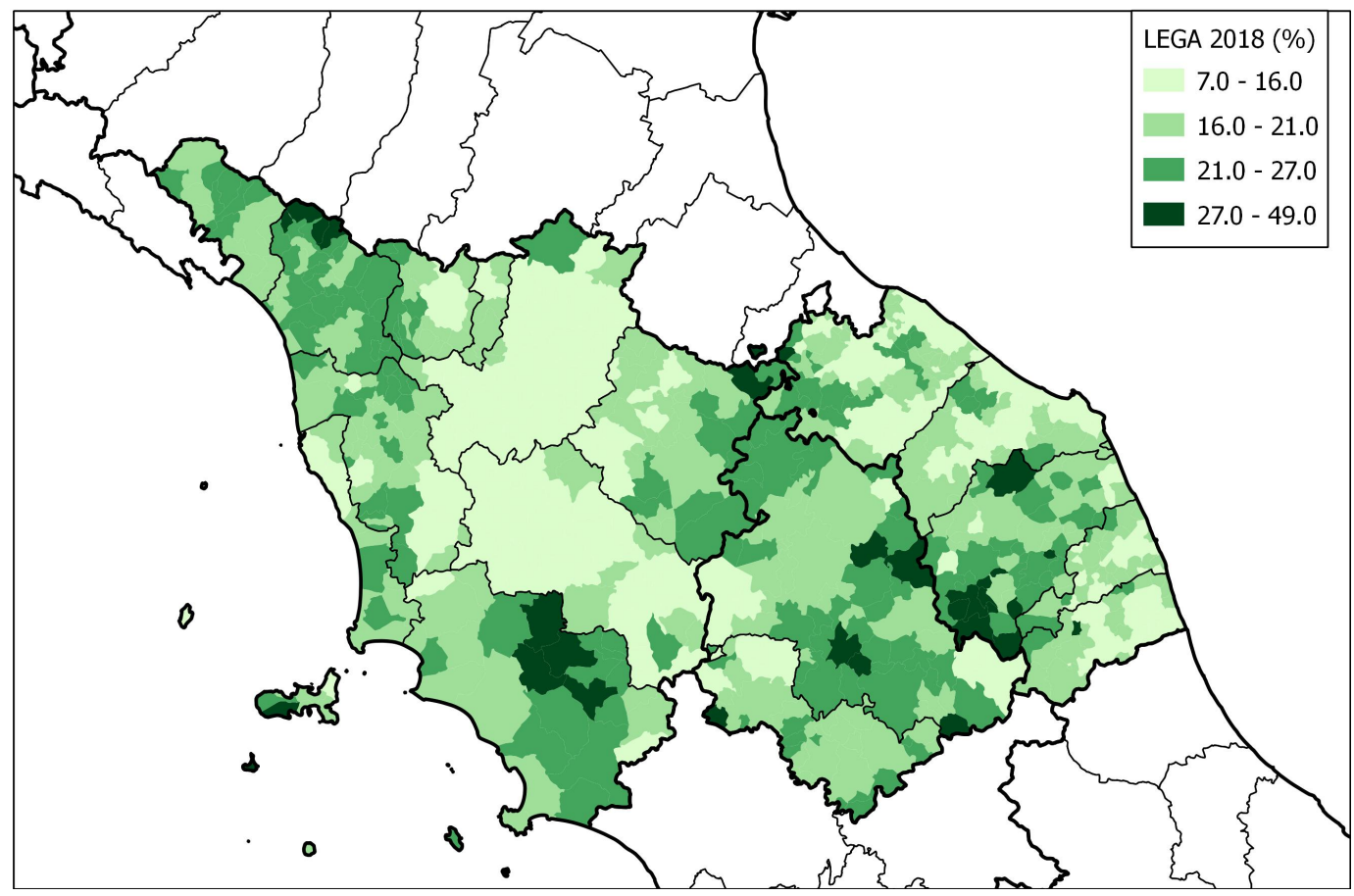

As shown in the maps, the MSI is stronger in the northern part of the Tuscany, and especially in the province of Lucca (see the upper-left section of the map). Moreover, the south-western part of the same region (the province of Grosseto) sees a significant performance of the party. For what regards Umbria and Marche, it is possible to see that the southern part of both the regions sees stronger support for MSI (especially, the southern municipalities of the province of Perugia and Macerata). Figure 2 shows the distribution of the vote shares of the Lega in $2008 . .^{5}$ As it is possible to see, the thematic map does not reproduce at all the MSI pattern. In 2008, the Lega proved stronger in places at the northern boundary of the three regions taken into consideration, consistently with the expansion-contraction trend of the party discussed by Segatti and Vezzoni (2011). Instead, the 2018 Lega map (figure 3) presents some analogies with that of the MSI of 1976. The Lega seems slightly stronger in the center-south of the region for what regards Umbria and (partially) Marche. The similarity between the two maps can also be seen in Tuscany (in the aforementioned provinces of Grosseto and Lucca). Summarizing, if the pattern of 2018 could

5 To show the spatial distribution of the votes for the Lega before Matteo Salvini's leadership, we provided data coming from 2008 national election, because of the higher variabilities among municipalities than in 2006 and 2013 elections, as Table 1 shows. Notwithstanding, similar patterns of the spatial distribution of the Lega are found even when considering 2006 and 2013 data. Results are available upon request. 
partially resemble the one of MSI in 1976, the pattern of 2008 seems pretty much uncorrelated with the map of MSI in 1976.

\subsection{Alternative explanations: Racial threat and modernization losers}

Although it seems that the explanation based on minority political traditions is intuitively consistent with the data presented above, other alternative explanations could confound the relation between Lega Nord exploit and post-fascist minority enclaves. In the European literature, the study of determinants of the vote for extreme right-wing parties emphasizes the social background of these parties support. Since early theories on working-class authoritarianism (Lipset, 1981), it has been stated that working-class people are more likely to vote for extreme right-wing parties (Bowyer, 2008). Betz (1994) suggests that the coming of a post-industrial society leads social risks (unemployment, poverty etc.) to mainly overthrow on specific groups, in particular on working-class individuals, on the elder and people with low educational levels. Once the social system that used to guarantee protection to these parts of the population weakened, the members of these more fragile groups start to look for their political representatives among that parties that offer the simplest solution to their everyday problems. In this way, the 'modernization losers' (that is, people who, in a way or another fit imperfectly in the labor market or are at risk of poverty and social exclusion, see Evans, 2005; Givens, 2005) seem to be the most favorable environment in which an extremist right-wing party can find its supporters. Empirical proofs of the fact that, for instance, unemployed are more prone to support right-wing parties has been found both at the individual (Evans, 2005; Givens, 2005) and at the aggregate level (Bowyer, 2008; Rydgren, and Ruth, 2013, Goodwin, Ford and Cutts, 2013).

The second set of explanations, that of the 'racial threat' (Bowyer, 2008; Ford and Goodwin, 2010) is far more precise in defining the trademarks of the strategies of European extreme right-wing parties. The theory argues that, as long as the prevalence of immigrants (or ethnic minorities) increases in a place, as long as the natives' majority of that place perceives the minority as a threat to their privileges, becoming more hostile towards the minority. The perception of threat by the indigenous community and the conflict that follows can be triggered

among various dimensions, such as the economic (conflicts concerning jobs, housing and welfare), or cultural one (language, traditions). Whatever the reason, it is possible to argue that 
when the size of one or more minority groups grow, the likelihood of a conflict increases. The empirical evidence of this argument presents mixed evidence: several studies (Givens, 2005; Bowyer, 2008) have found that the size of a particular minority increases the likelihood to vote for an extremist right-wing party. Other studies (e.g. Minkenberg and Schain, 2003) did not find any clear relation.

\subsection{Hypotheses}

Our argument concerns the trajectories that the Lega took to gain support in the red belt. We have argued that radicalization/nationalization of the party could have mobilized an extreme right-wing minority expected to vote other right-wing parties in the past and that now found the Lega as a valid alternative to those parties. If minority political traditions had an impact in the great electoral performance of the Lega in 2018, we should be able to identify a relationship between the geographical distribution of the post-fascist tradition in the red belt and the penetration in the territory of the Lega in 2018. In particular, we expect that the stronger the MSI performance has been during the First Republic, the stronger will be the Lega performance in 2018 national election (Hpl). This would be an indicator of the fact that the minority right-wing electorate in the zone recognized the nationalization of the new Lega message and accepted it.

The argument exposed so far is based on the fact that the Lega has changed both in terms of communication and in ideological alignment. The radicalization/nationalization process, under the leadership of Matteo Salvini, modified the political supply of the party and, in turn, could have modified perceptions that right-wing people of the red belt have towards the Lega itself. If this is true, the pattern we see in 2018 should be different with respect to that we have seen in previous elections (indirect evidence of this change have already been exposed when commenting figures 1-3). Thus, our second hypothesis is that the strength of the MSI in the First Republic will not be correlated with the strength of the Lega Nord in national elections previous to 2018 (Hp2).

We have stressed above that the process of nationalization/radicalization of the Lega can also be explained by contextual factors that favor xenophobic/right-wing parties around Europe. According to the theory of modernization losers, people who are threatened by processes of

globalization and technological advancement, in particular, the unemployed, will be more likely to vote for a xenophobic party. Moreover, dealing with the Lega as a generic right-wing party, the 
racial threat argument states that people living in an environment with a high prevalence of immigrants can see a right-wing/xenophobic party as a reliable loudhailer of the conservation of their privileges, threatened by foreigners. Our two hypotheses will thus be tested by taking into accounts these two alternative explanations, whose operationalization will be explained in the next section.

\section{Data, methods and models}

All data analyzed in this article are collected at the municipality level. Therefore, the ecological unit of analysis is the municipality, the most refined (in terms of number of voters) geo-referenced unit available. Electoral outcomes come from the Official Electoral Archive of the Italian Ministry of the Interior; they are therefore not affected by measurement error (except for some negligible material mistakes). The area taken into account concerns the three regions in the red belt of Tuscany, Umbria, and Marche. Consistently with the hypotheses, the analyses will employ as dependent variables the percentages of votes (divided by eligible voters) of the Lega in 2006, 2008, 2013 and 2018 national elections. ${ }^{6}$

To operationalize the post-fascist political tradition, which represents our main independent variable, following previous literature (Sani, 1976; Vezzoni, 2008) we employ the percentage of votes at the municipality level for the MSI in 1976, about forty to fifty years before the election here analyzed. Since we are dealing with a minority party, however, the simple correlation between the Lega and the MSI could be misleading, since the MSI coefficient could be moderated or even canceled by the effect of other traditions. With this respect, thus, we must control for other possible confounders. Since it has been argued that the consensus for the Lega proved to be higher in areas where the DC tradition is stronger, in the model that follows we will add the strength of Christian Democrats in 1976 in every municipality, in order to take into account possible composition effect.

\footnotetext{
6 The employment of measures concerning different elections (1976, 2006, 2008, 2013, 2018) requests some small administrative adjustments to the structure of the municipalities. Over time, indeed, some municipalities merged, others have been split. The issue (which involves a small number of cases) has been managed by finding a least common geographical structure that could preserve the structure of the municipalities in 2013 Elections. Therefore, the number of statistical units included in the analyses is slightly higher than the number of municipalities of Tuscany, Umbria, and Marche in 2018.
} 
Alternative explanations of modernization losers and racial threat are operationalized by including among the control variables respectively the percentage of unemployed and foreigners, both measured in 2011 for each municipality. Moreover, we control for the age dependency ratio (the number of over-65 inhabitants divided by the under-14, multiplied by 100) and the logarithm of the population, measured in 2015 at the municipality level ${ }^{7}$.

\subsection{Methods}

To test the geographical trajectories the Lega took for its exploit, we might employ OLS linear regression models. However, regression analyses on spatially contiguous observations could lead to issues of spatial dependence, in which the structure of the correlation between observations follows a specific (spatial) neighboring structure. Including spatial dependence in our models solves two kinds of problem: the first, technical, argues that if not adequately considered, an ordinary least squares regression model can include spatially auto-correlated errors (a violation of OLS's assumptions, which would lead to biased estimates). Secondly, the use of non-spatial models neglects a crucial characteristic of our data, that is, interdependence between ecological units.

A technique that accounts for interdependence between observations and leads to unbiased coefficients is the Spatial Autoregressive Model (SAR, see Ward and Gleditch, 2008). A SAR model can be written as follows:

$$
y=\rho W y+X \beta+\varepsilon i .
$$

In the right-side of the equation, $y$ is the dependent variable, $W$ is the spatial weight matrix, and $\rho$ is a spatial autoregressive coefficient. The 'spatial lag' operator $W y$ can be interpreted, if the weight matrix is row-standardized, as the average of the dependent variable of the neighbors of each ecological unit (Ward and Gledistch, 2008).

Weight matrices can be designed in different ways (Cliff and Ord 1970; Anselin, 1988). We chose to define the weight matrix as a $\mathrm{k}$-nearest neighbor, with $\mathrm{k}=4$. This because of the presence

\footnotetext{
7 Starting from 2016, some of the municipalities included in the analysis have merged together, therefore the most recent population data unique to every municipality refer to 2015 .
} 
of non-contiguous municipalities (e.g. small islands) which, having no neighbors, would have been excised from the analysis.

The regression model employed to test our first hypothesis can thus be expressed as follows:

$$
\text { Legal8 }=\text { Msi76 +Dc76 + Foreign }+ \text { Unemp }+ \text { AgeDep }+ \text { Population }+ \text { Region }+\rho \text { WLegal } 8
$$

In the equation, Legal8 is the percentage of votes for the Lega in 2018, Msi76 and Dc76 are respectively the percentage (on valid votes) of MSI and DC, Foreign is the percentage of foreigners, Unemp is the percentage of unemployed, AgeDep is the age dependency ratio (the number of over-65 divided by the under-14, multiplied by 100) Population is the natural logarithm of the population and Region is a set of dummy variables that indicates the region (whether Tuscany, Umbria and Marche). $\rho$ WLegal8 refers to the control for spatial autocorrelation of the dependent variable. All the variables are measured at the municipality level.

To test hypothesis 2, we test three analogous models, where the dependent variable is represented by the percentage of the Lega Nord vote at the municipality level respectively in 2006, 2008 and 2013 general elections. As well, in those models also the spatial autocorrelation term refers to the dependent variable employed. The other independent variables coincide with the ones of the model reported in the equation.

\section{Results}

Table 2 shows the results of the four SAR models. In Model 1, the dependent variable is represented by the share of valid votes for the Lega in 2018 general election, while in Model 2, 3, and 4 the dependent variable is the share of valid votes for the Lega in 2013, 2008, and 2006 elections. First, we can see that the rho coefficient, which indicates whether the spatial distribution of the dependent variable influences coefficients, is always positive and significant. ${ }^{8}$

\footnotetext{
8 All the models have also been estimated without the spatial autocorrelation term. Compared with OLS models, in all the cases SAR models proved to increase the fit (p-values of log-likelihood ratio tests $<0.05$ ). The output of the OLS models is available under request.
} 
For what concerns the effects of post-fascist minority tradition, the strength of the MSI leads to significantly increased percentages of the Lega in 2018 (see Model 1). Net of the other variables, a 1-percentage point increase in the share of votes to MSI in 1976 leads on average to an increase of the share of the vote to the Lega in 2018 of 0.32 percentage points. The coefficient provides empirical evidence to Hypothesis 1.

According to our expectations, the relation should not hold in previous elections, in which the Lega was less concerned to present itself as a national, right-wing party. Model 2, 3, and 4 show indeed that MSI coefficient, when the dependent variable is 2013, 2008, and 2006 Lega performance, is always negative, and even statistically significant at 0.10 level in 2013 . While 2018 Salvini's Lega performance seems to be driven by post-fascist minority tradition, the same does not apply for Bossi's (and Maroni's) old Lega. Therefore, empirical data confirm also Hypothesis $2 .{ }^{9}$

Differently from post-fascist tradition, a stronger DC tradition always leads to higher support for the Lega Nord in the red belt, at least in the period 2006-2018. This finding is consistent with previous analyses on Emilia-Romagna, the only 'red-belt' region where the Lega had obtained a not irrelevant consensus even before the 2013-2018 electoral cycle (Passarelli and Tuorto, 2012).

When looking at the alternative explanations of the Lega's vote, no clear evidence emerges in supporting the modernization losers' argument. Only in 2006, a higher unemployment rate seems to be associated with a higher consensus for the Lega Nord. The local prevalence of foreigners, on the contrary, increases Lega Nord strength in the red belt, even if slightly - an increase of 1 percentage point in the foreigners' prevalence increases the strength of the Lega by 0.09 percentage points in 2018. We can thus conclude that results are consistent with the racial threat argument, even if the coefficient suggests a slight correlation.

\section{Discussion and conclusions}

In 2018, the Lega over-performed in several Italian regions with respect to previous elections,

\footnotetext{
${ }^{9}$ Figure A1 in the Appendix provides further evidence of our hypothesis. Even when analyzing regional elections (in Tuscany, Marche, and Umbria), SAR models show that while in 2015 the relation with the MSI tradition and the share of votes for the League is positive and significant, the same does not apply in 2010. Moreover, in 2010 the relation proves to be negative.
} 
even in a part of the country which has been largely dominated by center-left parties and has never provided support for the Carroccio. Although this anomaly with respect to the past has been explained by supply-side factors (the nationalization/radicalization of the New Lega of Matteo Salvini and the drop in support of its historical ally, Berlusconi's Forza Italia), the present article aimed at studying whether political traditions played a role in the explanation of the territorial distribution of the Lega's vote.

Table 2. SAR models for the study of Lega Nord performances in general elections in the red belt.

\begin{tabular}{lcccc}
\hline & \multicolumn{4}{c}{ Lega $\%$} \\
& Model 1 & Model 2 & Model 3 & Model 4 \\
& 2018 & 2013 & 2008 & 2006 \\
\hline MSI '76 \% & $0.32^{* * *}$ & $-0.02^{*}$ & -0.04 & -0.01 \\
DC '76 \% & $(0.09)$ & $(0.01)$ & $(0.03)$ & $(0.01)$ \\
& $0.17^{* * *}$ & $0.006^{* *}$ & $0.02^{* * *}$ & $0.008^{* *}$ \\
Foreigners \% & $(0.02)$ & $(0.003)$ & $(0.01)$ & $(0.003)$ \\
& $0.09^{*}$ & 0.07 & $0.04^{* * *}$ & $0.02^{* * *}$ \\
Unemployment \% & $(0.05)$ & $(0.07)$ & $(0.01)$ & $(0.01)$ \\
& -0.03 & -0.04 & 0.06 & $0.07^{* *}$ \\
Age dependency ratio & $(0.02)$ & $(0.03)$ & $(0.06)$ & $(0.04)$ \\
Population (logarithm) & -0.002 & $-0.0007^{* * *}$ & $-0.0010^{*}$ & $-0.008^{* * *}$ \\
& $(0.002)$ & $(0.0002)$ & $(0.0006)$ & $(0.003)$ \\
Region: Tuscany (ref. Marche) & $-0.42^{* * *}$ & -0.01 & -0.04 & $-0.06^{*}$ \\
& $(0.16)$ & $(0.02)$ & $(0.05)$ & $(0.03)$ \\
Region: Umbria & $2.37^{* * *}$ & $0.10^{*}$ & 0.17 & $0.21^{* * *}$ \\
& $(0.40)$ & $(0.06)$ & $(0.13)$ & $(0.08)$ \\
Constant & $2.69^{* * *}$ & -0.03 & $-0.34^{* *}$ & $-0.22^{* *}$ \\
Rho & $(0.53)$ & $(0.07)$ & $(0.17)$ & $(0.10)$ \\
& $10.40^{* * *}$ & $0.79^{* * *}$ & 0.87 & 0.70 \\
\hline Observations & $(2.15)$ & $(0.28)$ & $(0.64)$ & $(0.38)$ \\
& $0.22^{* * *}$ & $0.13^{* *}$ & $0.35^{* * *}$ & $0.21^{* * *}$ \\
& $(0.05)$ & $(0.06)$ & $(0.05)$ & $(0.05)$ \\
\hline
\end{tabular}

Note: $* * * \mathrm{p}<0.01, * * \mathrm{p}<0.05, * \mathrm{p}<0.1$

Notwithstanding, our case study does not focus on the role of the major political subcultures, but with the 'black', post-fascist minority tradition within a context historically dominated by the 'red' subculture. After having stated the process of radicalization and nationalization operated by 
the new leader of the Lega, Matteo Salvini, we hypothesized that the Lega could have spread in the red belt selectively among the cluster of support that the neo-fascist minority had in the First Republic. We argued that this minority political tradition reacted to the ideological shift of the 'new' Lega, by contributing to the success of the Carroccio in the 2018 Elections. As the regression models presented in the previous paragraph show, the effect of the MSI tradition, the political reference of extreme-right in the First Republic, is large and significant, as well the effect of the DC tradition.

Results become even more evident if we consider, as dependent score, the spatial distribution of the 'old' Lega in 2008 national elections (as well as in 2006 and 2013 ones). At that time, however, the ideological switch was not yet performed, and the old leader's rhetoric was far more bounded into the limits of an ethno-regionalist ideology (less interesting for an electorate of the center of the country). In this situation, the relation between the post-fascist minority and the distribution of 2018 Lega is not significant, and the driving tradition is that of the Christian Democrat's minority.

Finally, we attempted to interpreting the Lega as a generic extreme right-wing party, and argued consistently that its uneven geographical distribution could be due to characteristics of the local context, such as the unemployment rate and the percentage of immigrants in the local environment: the literature shown that these two predictors could be connected with social mechanisms (respectively 'modernization losers' and 'racial threat') that could increase the voting likelihood for extreme right-wing parties (Bowyers, 2008; Ford and Goodwin, 2010). Regression models presented in the previous paragraph provided (little) evidence compatible with the sole racial threat argument.

Our results need to be taken with caution. First, we are conscious that no causal claims can be assessed and mechanisms explaining the success of the Lega cannot be tested through the data here employed. We just aimed to provide empirical evidence to two theoretically framed hypotheses, using ecological correlations. Second, this work does not aim at explaining why the Lega obtained such an outstanding performance in the red belt in the 2018 elections. MSI performance in the red belt was, on average, rather weak during the First Republic; therefore, it is unlikely that such a minority tradition represents the main driver of the recent success of the Lega. Third, analyses refer only to three regions of the red belt; thus, we cannot draw any conclusion towards the post-fascist inheritance on the vote for the Lega Nord in other regions. If the Lega 
will continue in its process of electoral expansion, future research is expected to test our hypotheses even in other center regions and in southern regions, by focusing on the areas where the MSI political tradition was stronger than in any provinces of the red belt.

Our contribution provides new insights on the territorial distribution of the vote for the Lega. In this respect, we analyze whether minority political traditions which proved to be stronger in certain places persist and are related to the actual voting patterns. Despite the electoral earthquake and the unprecedented volatility which characterized both 2013 and 2018 national elections, as well as the progressive loss in the explanatory power of traditional cleavages when analyzing voting behavior, territorial patterns of vote seem somehow to persist, meaning that political traditions can still affect voting behavior. More interestingly, our findings suggest a certain dynamicity of the effects of political traditions that adapt to the transformations of the electoral supply. Moreover, the focus on the inheritance of the minority political traditions represents a promising perspective in the study of voting behavior, which actualizes Sani's (1976) arguments. 


\section{References}

Agnew, J. (1992). Place and politics in post-war Italy: A cultural geography of local identity in the provinces of Lucca and Pistoia. In Anderson, K., \& Gale, F. (Eds.), Inventing places: studies in cultural geography. Melbourne: Longman Cheshire, 52-71

Agnew, J. (1995). The rhetoric of regionalism: The Northern League in Italian politics, 1983-94. Transactions of the Institute of British Geographers, 20 (2), 156-172.

Agnew, J. (1996). Mapping politics: how context counts in electoral geography. Political Geography, 15(2), 129-146.

Albertazzi, D. (2016). Going, going,... not quite gone yet? "Bossi's Lega" and the Survival of the Mass Party. Contemporary Italian Politics 8(2), 115-130.

Albertazzi, D., Giovannini, A., \& Seddone, A. (2018). 'No regionalism please, we are Leghisti!'The transformation of the Italian Lega Nord under the leadership of Matteo Salvini. Regional \& Federal Studies, 1-27. Online first view.

Anderlini, F. (2007). Una frontiera italiana. Il Mulino, 56 (4), 644-652.

Anselin, L. (1988). Spatial econometrics: Methods and models. Dordrecht: Kluwer Academic.

Baccetti, C., \& Gabelli, M. (1998). Una prima falla nella Toscana rossa? La vittoria del centro-destra nelle elezioni comunali del 27 aprile 1997 a Grosseto. Quaderni dell'Osservatorio Elettorale, 40(2), 1-37

Beirich, H., \& Woods, D. (2000). Globalisation, workers and the northern league. West European Politics, 23(1), 130-143.

Betz, H.-G. (1994). Radical Right-wing Populism in Western Europe. New York: St. Martin's Press.

Bordignon, F., \& Ceccarini, L. (2015). The Five-Star Movement: a hybrid actor in the net of state institutions. Journal of Modern Italian Studies, 20(4), 454-473.

Bowyer, B. (2008). Local context and extreme right support in England: The British National Party in the 2002 and 2003 local elections. Electoral Studies, 27(4), 611-620.

Brunazzo, M., \& Gilbert, M. (2017). Insurgents against Brussels: Euroscepticism and the right-wing populist turn of the Lega Nord since 2013. Journal of Modern Italian Studies, $22(5), 624-641$.

Cartocci, R. (1994). Fra Lega e Chiesa. Bologna: Il Mulino. 
Cento Bull, A., \& Gilbert, M. (2001). The Lega Nord and the northern question in Italian politics. New York: Palgrave.

Corbetta, P., Pedrazzani, P., Pinto, P., \& Vignati, R. (2015). Elezioni regionali 2015: I flussi elettorali a La Spezia, Padova, Livorno, Perugia, Napoli, Salerno, Foggia. Bologna: Istituto Cattaneo

Cliff, A. D., Ord. J. K. (1970). Spatial autocorrelation: A review of existing and new measures with applications. Economic Geography, 46(2):269-292

D’Alimonte, R. (2015). Grillo resta secondo partito, Lega prima nel centrodestra. In Paparo, A., \& Cataldi, M. (Eds.), Dopo la luna di miele. Le elezioni comunali e regionali fra autunno 2014 e primavera 2015, 229-232, Roma: Centro Italiano di Studi Elettorali.

Diamanti, I. (1993). La lega, imprenditore politico della crisi. origini, crescita e successo delle leghe autonomiste in Italia. Meridiana, 16, 99-133.

Diamanti, I. (2003). Bianco, rosso, verde... e azzurro. Mappe e colori dell'Italia politica. Bologna: il Mulino.

Diamanti, I. (2015). Salvini-Le Pen, relazioni pericolose, La Repubblica, May 18.

Dogan, M. (1967). Political cleavages and social stratification in France and Italy. In Lipset, S.M., \& Rokkan, S. (Eds.), Party systems and voter alignments. New York: The Free Press, $129-195$.

Evans, J. A. J. (2005) The dynamics of social change in radical right-wing populist support Comparative European Politics, 3(1), 76-101.

Ford, R., \& Goodwin, M. J. (2010). Angry white men: individual and contextual predictors of support for the British National Party. Political Studies, 58(1), 1-25.

Galli, G. (Ed.) (1968). Il comportamento elettorale in Italia: Un'indagine ecologica sulle elezioni in Italia tra il 1946 e il 1963. Bologna: il Mulino.

Givens, T. E. (2005) Voting Radical Right in Western Europe. New York: Cambridge University Press.

Goodwin, M., Ford, R., \& Cutts, D. (2013). Extreme right foot soldiers, legacy effects and deprivation A contextual analysis of the leaked British National Party (BNP) membership list. Party Politics, 19(6), 887-906.

Hix, S., \& Marsh, M. (2007). Punishment or protest? Understanding European Parliament elections. Journal of Politics, 69(2), 495-510. 
Ignazi, P. (1994). Postfascisti? La trasformazione del Movimento sociale in Alleanza nazionale. Bologna: il Mulino.

Ignazi, P. (2003). Radical Extreme Right Parties in Western Europe. Oxford: Oxford University Press.

Lipset, S. M. (1981). Political Man. Baltimore: Johns Hopkins University Press.

Minkenberg, M, \& Schain, M. (2003) The Front National in context: French and European dimensions. In Merkl, P. H., \& Weinberg, L. (Eds.), Right-wing extremism in the twenty-first century. London: Frank Cass Publishers, 161-190.

Paparo, A., Cataldi, M. (2018). A Prato i voti di Monti non premiano Renzi, e il centrosinistra cede al centrodestra. Roma: Centro Italiano di Studi Elettorali.

Passarelli, G., \& Tuorto, D. (2009). La Lega Nord oltre il Po. Il Mulino, 58(4), 663-670.

Passarelli, G., \& Tuorto, D. (2012). The Lega Nord goes south: The electoral advance in Emilia-Romagna: A new territorial model?. Political Geography, 31(7), 419-428.

Reif, K. (1984). National electoral cycles and European elections 1979 and 1984. Electoral Studies, 3(3), 244-255.

Reif, K., \& Schmitt, H. (1980). Nine second-order national elections. A conceptual framework for the analysis of European election results. European Journal of Political Research, 8(1), $3-44$.

Robbins, J. W., \& Hunter, L. Y. (2012). Impact of electoral volatility and party replacement on voter turnout levels. Party Politics, 18(6), 919-939.

Rydgren, J., \& Ruth, P. (2013). Contextual explanations of radical right-wing support in Sweden: socioeconomic marginalization, group threat, and the halo effect. Ethnic and Racial Studies, 36(4), 711-728.

Sani, G. (1976). Political traditions as contextual variables: Partisanship in Italy." American Journal of Political Science, 20 (3), 375-405.

Segatti, P., and Vezzoni, C. (2011),. Alla ricerca del limes padano. LIMES, 2011 (2), 59-70

Shin, M. E., \& Agnew, J. A. (2002). The Geography of Party Replacement in Italy, 1987-1996. Political Geography, 21 (2), 221-242.

Shin, M. E., \& Agnew, J. A. (2007). The Geographical Dynamics of Italian Electoral Change, 1987-2001. Electoral Studies 26 (2). 287-302.

Shin, M. E., \& Agnew, J. A. (2008). Berlusconi's Italy: Mapping contemporary Italian politics. 
Philadelphia: Temple University Press.

Tarchi, M. (1998). The Lega Nord. In De Winter, L. (Ed.), Regionalist Parties in Western Europe. London: Routledge.

Tassani, G. (1990). The Italian social movement: from Almirante to Fini. Italian Politics, 4, 124-145.

Trigilia, C. (1986). Grandi partiti e piccole imprese. Bologna: il Mulino

Vezzoni, C., \& Mancosu, M. (2016). Diffusion processes and discussion networks: An analysis of the propensity to vote for the 5 Star Movement in the 2013 Italian election. Journal of Elections, Public Opinion and Parties, 26(1), 1-21.

Vignati, R. (2018). Dal Pd al M5s, dal M5s alla Lega: analisi degli spostamenti di voto. In Valbruzzi, M., \& Vignati, R. Il vicolo cieco: Le elezioni politiche del 4 marzo 2018. Bologna: il Mulino. 185-211.

Ward, M. D., Gledistch, K. S. (2008). Spatial regression models. Los Angeles: Sage 


\section{Appendix}

Table A1. SAR models for the study of Lega Nord performances in 2010 and 2015 regional elections in the red belt.

\begin{tabular}{lcc}
\hline & & $\%$ Lega \\
& 2015 & 2010 \\
\hline MSI '76\% & $0.15^{* * *}$ & $-0.11^{* * *}$ \\
DC '76\% & $(0.04)$ & $(0.04)$ \\
& $0.03^{* * *}$ & $0.03^{* * *}$ \\
Foreigners \% & $(0.01)$ & $(0.01)$ \\
& $0.07^{* * *}$ & $0.07 * * *$ \\
Unemployment \% & $(0.02)$ & $(0.02)$ \\
& -0.09 & 0.03 \\
Age dependency ratio & $(0.09)$ & $(0.08)$ \\
& $-0.003^{* * *}$ & $-0.003 * * *$ \\
Population (logarithm) & $(0.001)$ & $(0.001)$ \\
& 0.04 & -0.07 \\
Region: Tuscany (ref. Marche) & $(0.07)$ & $(0.06)$ \\
& $2.25^{* * *}$ & 0.11 \\
Region: Umbria & $(0.20)$ & $(0.18)$ \\
& $1.77^{* * *}$ & $-0.82^{* * *}$ \\
Constant & $(0.26)$ & $(0.23)$ \\
Rho & $3.06^{* * *}$ & $2.63 * * *$ \\
& $(0.98)$ & $(0.89)$ \\
\hline Observations & $0.12^{* *}$ & $0.20 * * *$ \\
Nagelkerke R ${ }^{2}$ & $(0.05)$ & $(0.05)$ \\
\hline
\end{tabular}

Note: $* * * \mathrm{p}<0.01, * * \mathrm{p}<0.05, * \mathrm{p}<0.1$ 